\title{
ZAWODNOŚCI PAŃSTWA W ROZWIAZZYWANIU PROBLEMU DÓBR WSPÓLNYCH - NA PRZYKŁADZIE WSPÓLNEJ POLITYKI RYBOŁÓWSTWA UNII EUROPEJSKIEJ
}

\section{WSTĘP}

Problem dóbr wspólnych (ang. the tragedy of the commons) pojawia się wtedy, gdy zbyt wielu użytkowników ekstensywnie korzysta ze specyficznej kategorii dóbr publicznych, takich jak: drogi, lasy, łowiska, tereny rekreacyjne, parki krajobrazowe itp. Dobro możemy nazwać publicznym, gdy w jego przypadku pojawia się sytuacja niekonkurencyjności i/lub „niewykluczalności” z użytkowania - odpowiednie przykłady pokazuje tabela 1 . Tak zwane dobra wspólne (ang. common pool resources) cechuje - mniej lub bardziej nasilona - konkurencja w korzystaniu $\mathrm{z}$ ich ograniczonych zasobów oraz (całkowity lub częściowy) brak możliwości ograniczania poszczególnym użytkownikom dostępu do tych zasobów.

Kwestia zawodności koordynacji rynkowej w alokacji i produkcji dóbr wspó1nych została najszerzej chyba rozpropagowana dzięki - opublikowanemu w 1968 roku w miesięczniku „Science” - kontrowersyjnemu ${ }^{1}$ artykułowi biologa G. Hardina ${ }^{2}$. Hardin użył w nim sformułowania tragedy of the commons, gdyż jako biologa w szczególności bulwersowała go kwestia wyczerpywania się rozmaitych zasobów przyrodniczych, które w wyniku użytkowania przez stale rosnącą populację ludzi mogą zostać skazane na bezpowrotne zniszczenie ${ }^{3}$ - przykładowo coraz bardziej

\footnotetext{
${ }^{1}$ Por. np. I. Angus, Debunking the 'Tragedy of the Commons', tekst dostępny na stronie: http:// links.org.au/node/595 (3.10.2009).

${ }^{2}$ G. Hardin, The Tragedy of the Commons, „Science” 1968, no. 162, s. 1243-1248. Hardin w swoim artykule wskazuje jednak, że problem ten opisywano już wcześniej, np. w pracy: W. F Lloyd, Two Lectures on the Checks to Population, Oxford University Press, Oxford 1833.

${ }^{3}$ Hardin opatrzył swój artykuł mottem: The population problem has no technical solution - it requires a fundamental extension in morality, którym chciał podkreślić, iż - jego zdaniem - rozwią-
} 
ekstensywne poławianie ryb morskich może doprowadzić do ich całkowitego wyginięcia.

Celem niniejszego artykułu jest pokazanie, że koordynacja rynkowa może być efektywnym rozwiązaniem „tragedii” dóbr wspólnych pod warunkiem, że zostaną zdefiniowane silne prawa własności do tych zasobów i będą one następnie respektowane (co pozwoli na wykluczanie nadmiernej liczby użytkowników). Kwestia ta została w szczególności pokazana na przykładzie gospodarowania łowiskami przez UE i jej kraje członkowskie.

Tabela 1. Charakter dóbr ze względu na cechy użytkowania

\begin{tabular}{|c|}
\hline Cechy użytkowania \\
\hline $\begin{array}{l}\text { Wykluczalność (ang. exclusion) } \\
\text { Niewykluczalność }\end{array}$ \\
\hline Konkurencyjność (ang. rivalry) \\
\hline $\begin{array}{c}\text { czyste dobra } \\
\text { prywatne: } \\
\text { szczoteczka do zębów, mieszkanie } \\
\text { dobra publiczne-wspólne: } \\
\text { (common pool resources) } \\
\text { lasy, łowiska ryb }\end{array}$ \\
\hline Niekonkurencyjność \\
\hline $\begin{array}{c}\text { dobra publiczne - } \\
\text { klubowe: } \\
\text { telewizja kablowa, } \\
\text { koncert w filharmonii } \\
\text { czyste dobra } \\
\text { publiczne: } \\
\text { bezpieczeństwo wewnętrzne kraju, telewizja publiczna }\end{array}$ \\
\hline
\end{tabular}

Źródło: opracowanie własne na podstawie: J. M. Perloff, Microeconomics, Addison-Wesley 1999, s. 683.

\section{„TRAGEDIA DÓBR WSPÓLNYCH" NA GRUNCIE TEORII EKONOMII}

Nieoptymalna, nadmierna eksploatacja dóbr wspólnych jest najczęściej ilustrowana przykładem wykorzystywania przez grupę rolników wspólnej (np. gminnej) łąki ${ }^{4}$ do wypasu krów w celu produkcji mleka bądź mięsa (przykład ten pojawił się też w powoływanym wcześniej artykule G. Hardina).

zanie „tragedii” wyczerpywania się rzadkich zasobów przyrodniczych wymaga istotnych zmian światopoglądowych - por. G. Hardin, op. cit., s. 1243.

${ }^{4}$ I stąd również popularna w odniesieniu do opisywanego zjawiska nazwa „tragedia wspólnego pastwiska" - por. np. http://pl.wikipedia.org/wiki/Tragedia_wspólnego_pastwiska. 
Rysunek 1 prezentuje przykładowe wyjaśnienie „tragedii wspólnego pastwiska” za pomocą analizy przychodów i kosztów (całkowitych i krańcowych). Wyjaśnienie to zakłada, że żadnemu $z$ uprawnionych do korzystania $z$ łąki hodowców nie można w żaden sposób ograniczyć dostępu do tegoż pastwiska. Indywidualne wybory farmerów - maksymalizujących własny zysk - spowodują, że łączna liczba krów wypasanych na łące będzie wynosiła $q^{\text {int }}$ i będzie znacznie większa niż optymalna $q$ ", czyli taka, która zapewnia największy łączny zysk wszystkich użytkowników pastwiska. Funkcja $T R(q)$ (oznaczona linią przerywaną) pokazuje całkowite przychody (np. ze sprzedaży mleka) otrzymywane razem przez wszystkich hodowców z łącznej liczby ${ }^{5} q$ krów wypasanych przez nich na wspólnej łące. Przyjęto, że występuje tu klasyczne prawo malejących przychodów krańcowych (tj. $T R^{\prime} q>0$ i $T R " q<0$ ). Z kolei funkcja $T C(q)$ (oznaczona linią ciągłą) pokazuje wspólne koszty ponoszone przez hodowców przy założeniu, że koszt wypasu każdej dodatkowej krowy na pastwisku jest taki sam (koszt krańcowy jest stały i w tym przykładzie wynosi $k)^{6}$.

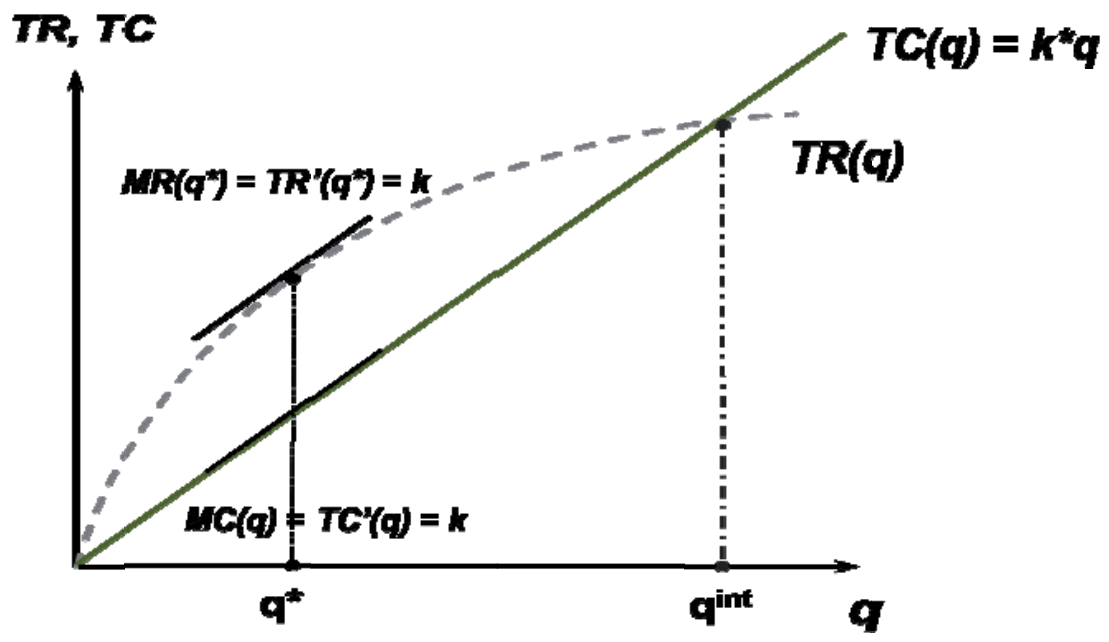

Rysunek 1. Nadmierne, nieoptymalne wykorzystanie dóbr wspólnych Źródło: opracowanie własne.

${ }^{5}$ Choć w rzeczywistości liczba krów może przyjmować wyłącznie wartości ze zbioru liczb naturalnych, to dla możliwości przeprowadzenia dowodu na podstawie rachunku korzyści i kosztów krańcowych przyjęto, że $q$ przyjmuje wartości ze zbioru dodatnich liczb rzeczywistych (jest zmienną ciągłą) tak, aby funkcje przychodów i kosztów całkowitych były różniczkowalne.

${ }^{6}$ Identyczne rozwiązanie (zbyt duża hodowla krów) pojawi się również przy założeniu rosnących kosztów krańcowych. Wybrany przypadek ma jedynie uprościć graficzną prezentację optimum ogólnego - na rysunku 1 widać wówczas dobrze, że przychód krańcowy (odpowiedni tangens stycznej do krzywej przychodów całkowitych) dla liczby wypasanych krów równej $q$ * wynosi $k$. 
Największy łączny zysk $T P(q)$ hodowcy osiągnęliby, gdyby zdecydowali się wypasać krowy w liczbie $q^{*}$ (na rysunku 1 widać, że wówczas różnica między łącznymi przychodami rolników i ich wspólnymi kosztami jest największa), co można również dowieść za pomocą rachunku marginalnego:

$$
\max _{q \geq 0} T P(q)=T R(q)-T C(q) .
$$

Warunek konieczny (a w tym przypadku i wystarczający) maksimum zysku:

$$
T P^{\prime}(q)=T R^{\prime}(q)-T C^{\prime}(q)=0 .
$$

Jeżeli przychody krańcowe oznaczymy $M R(q)$, a koszty krańcowe $M C(q)$ oraz:

$$
M R q=T R^{\prime} q \quad \text { i } \quad M C q=T C^{\prime} q=k .
$$

to rozwiązaniem jest (powszechnie znany w ekonomii) warunek, że maksymalny zysk - w tym przypadku tożsamy z „dobrobytem” ogółu hodowców - osiągnięty zostanie w sytuacji, w której przychód krańcowy zrówna się kosztem krańcowym (w tym przypadku stałym i równym $k$ ):

$$
M R q^{*}=M C q^{*}=k .
$$

Należy jednak zauważyć, że przy hodowli na optymalnym poziomie $q^{*}$ przeciętny zysk z wypasu jednej krowy $A P\left(q^{*}\right)$ jest dodatni i równy:

$$
A P\left(q^{*}\right)=\frac{T P\left(q^{*}\right)}{q^{*}}=\frac{T R\left(q^{*}\right)}{q^{*}}-k .
$$

Ten dodatni przeciętny zysk jednostkowy (uzyskiwany z hodowli jednej krowy) jest zachętą dla każdego pojedynczego farmera do tego, by zwiększać liczbę swoich krów na wspólnej łące. Podjęcie takiej decyzji zwiększa indywidualny zysk danego hodowcy, ale oczywiście pogarsza wyniki ekonomiczne wszystkich pozostałych. Zgodnie z przewidywaniami neoklasycznej ekonomii poszczególni hodowcy (kierujący się interesem własnym) będą zwiększać liczbę wypasanych krów do momentu, aż przeciętny zysk z wypasu jednej krowy będzie zerowy (czyli pojawi się sytuacja, w której indywidualna decyzja o zwiększeniu własnej produkcji nie przyniesie żadnych dodatkowych korzyści). Będzie to miało miejsce wtedy, gdy ogólna liczba krów na wspólnym pastwisku ukształtuje się na poziomie $q^{\text {int }}$, bo wówczas: 


$$
A P\left(q^{i n t}\right)=\frac{T P\left(q^{i n t}\right)}{q^{i n t}}=\frac{T R\left(q^{i n t}\right)}{q^{i n t}}-k=0 .
$$

Tak duży poziom produkcji powoduje, że łączne zyski hodowców maleją do zera (co oznacza, że jeżeli niektórzy z nich osiągają zyski, to inni ponoszą straty), a w skrajnym przypadku łąka jest eksploatowana w nadmierny sposób, który prowadzi do jej zniszczenia.

Opisany wyżej przypadek użytkowania wspólnego pastwiska jest subkategorią zjawiska „jazdy na gapę" (ang. free rider problem). Zjawisko to prowadzi do błędów w optymalizacyjnym działaniu koordynacji rynkowej w zakresie produkcji, alokacji czy konsumpcji dóbr publicznych, a w celu usunięcia tych błędów postuluje się często wprowadzenie rozmaitych rozwiązań „pozarynkowych”, w tym interwencji państwa.

Oprócz neoklasycznych modeli bazujących na modelu bomo oeconomicus (takich jak wcześniej omówiony przypadek „tragedii wspólnego pastwiska”) do wyjaśniania decyzji ludzi w sytuacji dylematu „wolnej jazdy” wykorzystuje się również:

- przewidywania teorii gier (np. z użyciem gry „dylemat więźnia”), na podstawie których decyzje te bada się również eksperymentalnie ${ }^{8}$;

- teorie psychosocjologiczne ${ }^{9}$, które zakładają, że ludzie mają społecznie utrwaloną skłonność do kooperacji, a związku z tym są skłonni maksymalizować dobrobyt ogólny.

Obserwacje rzeczywistości gospodarczej i eksperymenty laboratoryjne ${ }^{10}$ pokazują, że teorie te są raczej komplementarne (a nie konkurencyjne), zachowania ludzi mają bowiem $w$ takich przypadkach raczej złożony charakter. $Z$ jednej strony, ludzie wykazują skłonność do współpracy czy nawet altruizmu, a z drugiej - potrafią „chłodno” skalkulować, że ,jazda na gape” jest dla nich najbardziej opłacalnym rozwiązaniem.

Wydaje się, że nie ma uniwersalnych rozwiązań tego problemu, również w odniesieniu do dóbr wspólnych ${ }^{11}$. Ludzie wykazują skłonność do ,jazdy na gapę”,

${ }^{7}$ Szersze omówienie tych kwestii można znaleźć w: R. M. Jakubowski, P. Kuśmierczyk, $W y$ twarzanie dóbr publicznych a problem ,jazdy na gapę”, [w:] B. Polszakiewicz, J. Boehlke (red.), Wtasnośc $i$ kontrola w teorii i praktyce, cz. 1, Wydawnictwo Uniwersytetu Mikołaja Kopernika, Torun 2007, s. 163-184.

${ }^{8}$ Por. np. The Handbook of Experimental Economics, ed. J. H. Kagel, A. E. Roth, Princeton University Press, Princeton 1995, s. 26-40 i 111-195.

${ }^{9}$ Por. np. J. Andreoni, Cooperation in Public-Goods Experiments: Kindness or Confusion?, „The American Economic Review” 1995, vol. 85, no. 4, s. 891-904.

${ }^{10}$ Por. np. R. M. Jakubowski, P. Kuśmierczyk, Problem „jazdy na gape” - badania eksperymentalne, [w:] B. Polszakiewicz, J. Boehlke (red.), Wtasnośc i kontrola w teorii i praktyce, cz. 2, Wydawnictwo Uniwersytetu Mikołaja Kopernika, Toruń 2008, s. 101-116.

${ }^{11}$ Por. np. E. Ostrom, How Types of Goods and Property Rights Jointly Affect Collective Action, "Journal of Theoretical Politics" 2003, vol. 15, no. 3, s. 239-270. 
ale odpowiednie rozwiązania instytucjonalne są $\mathrm{w}$ stanie $\mathrm{w}$ znacznym stopniu ograniczyć negatywne, ekonomiczne konsekwencje tego zjawiska. Historycznym rozwiązaniem problemu ekstensywnego użycia gminnych łąk w Anglii były grodzenia i wyodrębnianie prywatnej własności pastwisk. Badania - nagrodzonej w 2009 roku Nagrodą Nobla - E. Ostrom pokazują, iż dobra wspólne mogą być efektywnie zarządzane również w przypadku ich publicznej (czy rozproszonej, np. spółdzielczej) własności ${ }^{12}$, a nie tylko poprzez ich sprywatyzowanie czy poddanie centralnemu sterowaniu przez wyznaczone agendy państwowe. Dotychczasowe badania naukowe i praktyczne doświadczenia pokazują, że dla każdego konkretnego dobra publicznego efektywne rozwiązania instytucjonalne powinny być uważnie dobrane tak, by odpowiadały charakterowi tego dobra, preferencjom (czy cechom moralnym) osób, które mają z niego korzystać, aktualnej sytuacji społecznej, politycznej i gospodarczej itd. ${ }^{13}$ Jak się wydaje, dobitnym przykładem na potwierdzenie tej tezy mogą być kolejne reformy Wspólnej Polityki Rybołówstwa Unii Europejskiej („ochrzczonej” już zresztą mianem „najgłupszej polityki UE"14).

\section{POLITYKA RYBOŁÓWSTWA UE ${ }^{15}$ A PROBLEM PRZEŁOWIENIA RYB W AKWENACH EUROPEJSKICH}

Unia Europejska posiada drugą co do wielkości (po Chinach) flotę połowową na świecie ${ }^{16}$. Rybołówstwo i różnego rodzaju akwakultury tworzą wiele miejsc pracy i zwiększają dobrobyt w nadmorskich regionach Europy. Jednakże zasoby ryb przemieszczają się w wodach morskich, przekraczając swobodnie granice państw, a ich własność zostaje określona dopiero, gdy zostaną one odłowione. Skutkuje to konfliktami wśród państw korzystających ze wspólnych łowisk, a spory odnośnie do praw połowowych nasilają się, gdy zasoby ryb (czy owoców morza) ulegają wyczerpaniu. Oznacza to konieczność tworzenia odpowiednich umów międzynarodowych, których podstawowym priorytetem jest takie ograniczenie połowów, by możliwa była odbudowa wyczerpujących się łowisk. W przypadku Unii Euro-

${ }^{12}$ Eadem, Governing the Commons: The Evolution of Institutions for Collective Action, Cambridge University Press, Cmbridge 1990.

${ }_{13}$ Por. np. B. Daniels, Emerging Commons and Tragic Institutions, „Environmental Law” 2007, vol. 37; B. R. Copeland, S. M. Taylor, Trade, Tragedy, and the Commons, „American Economic Review" 2009, vol. 99 (3).

${ }^{14}$ Por. Ł. Wójcik, Ryba psuje się od Unii, „Przekrój” 2009, nr 20.

${ }^{15}$ Szczegółowe informacje na ten temat można znaleźć na oficjalnej stronie internetowej Komisji Europejskiej poświęconej polityce rybołówstwa UE i jej reformom: http://ec.europa.eu/fisheries/reform/index_pl.htm (11.10.2009).

${ }^{16} \mathrm{http}: / / w w w . e u 4 j o u r n a l i s t s . e u /$ index.php/dossiers/polish/C8/35/ (13.10.2009). 
pejskiej umowy te muszą być zawierane zarówno między krajami członkowskimi, jak i z krajami spoza UE ${ }^{17}$. W takiej sytuacji ustanowienie Wspólnej Polityki Rybołówstwa Unii Europejskiej (dalej określanej skrótem WPR) było raczej koniecznością ${ }^{18}$ - jej pierwsze zasady ustalono w 1970 roku, jednak właściwa WPR weszła w życie dopiero w styczniu 1983 roku i była nowelizowana w 1992 oraz w 2002 roku (i zmieniała się wraz z kolejnymi rozszerzeniami UE, zwłaszcza $\mathrm{z}$ akcesją Portugalii i Hiszpanii, kiedy to flota europejska podwoiła się). Rezultaty prowadzonej od prawie 40 lat unijnej polityki rybołówstwa są następujące ${ }^{19}$ :

- ok. 88\% zasobów ryb w wodach europejskich jest zbyt intensywnie eksploatowanych (średnia światowa to ok. 25\%);

- ok. 30\% zasobów przekroczyło "granicę bezpieczeństwa” - pewne gatunki ryb nie mogą się już naturalnie odradzać, gdyż istniejąca populacja reproduktorów jest zbyt mała ${ }^{20}$;

- większość unijnych flot rybackich jest zbyt duża (szacuje się, że w niektórych przypadkach nawet o 80\%) i dokonuje nadmiernych połowów, często dwu-, a nawet trzykrotnie przekraczających naukowo określane limity, wynikające z biologicznych możliwości reprodukcyjnych;

- większość unijnych flot jest nierentowna lub operuje na granicy rentowności (ponosi straty lub osiąga niskie zyski) pomimo dotacji, jakie otrzymuje celem utrzymania miejsc pracy ${ }^{21}$;

- wielkość połowów spadła do takiego stopnia, że obecnie ok. dwie trzecie ryb (oraz owoców morza) dostępnych na rynkach europejskich pochodzi z im-

${ }^{17}$ Komisja Europejska negocjuje szereg umów dotyczących rybołówstwa z krajami skandynawskimi, afrykańskimi oraz na terenie Oceanu Indyjskiego i Spokojnego. UE ma status członka w większości regionalnych organizacji rybołówstwa, które ustanawiają zasady dla rybołówstwa morskiego.

${ }^{18}$ Radykalni krytycy WPR uważają, że państwo w ogóle nie powinno regulować rybołówstwa - wydaje się jednak, że często mylą oni wolny rynek (z silnie zdefiniowanymi prawami własności) z całkowitą a narchią. Jako przykład może tu służyć Somalia, gdzie od dłuższego czasu nie funkcjonuje praktycznie żaden rząd. „Somalijskie wody terytorialne zostały dosłownie ogołocone z ryb przez obce (między innymi hiszpańskie) kutry, więc biedni somalijscy rybacy przerzucili się na porywanie przepływających w pobliżu tankowców” - Ł. Wójcik, op. cit.

${ }^{19}$ Według ocen przeprowadzonych w 2008 r. przez Międzynarodową Radę Badań Morza (ICES) - por. Zielona Ksiegga. Reforma wspólnej polityki rybotówstwa, KWE, Bruksela 22.04.2009 - pełny tekst do pobrania na: http://eur-lex.europa.eu/LexUriServ/LexUriServ.do?uri= COM:2009:0163:FIN:PL:PDF (30.09.2009).

${ }^{20}$ Zagrożone gatunki to głównie: dorsz, śledź i sardela; przykładowo 93\% osobników dorsza w Morzu Północnym jest łowione, zanim może odbyć tarło - por. http://ec.europa.eu/news/environment/091016_pl.htm (7.10.2009).

${ }^{21}$ Szacunki pokazują, że w kilku państwach członkowskich koszty, jakimi sektor rybołówstwa obciąża budżet publiczny, przewyższają całkowitą wartość połowów - por. Zielona Ksiega..., s. 9. 
portu, a ceny detaliczne ryb $\mathrm{z}$ łowisk europejskich są często wyższe niż np. ryb pochodzących z Chin czy Wietnamu.

Mamy więc do czynienia z prawdziwą, „hardinowską” tragedią dóbr wspólnych, tyle że jej przyczyną nie jest (opisywana w poprzednim punkcie) zawodność koordynacji rynkowej, a błędy daleko posuniętego interwencjonizmu państwowego. Unijna polityka rybołówstwa ,jest regulowana przez szereg niezmiernie szczegółowych rozporządzeń, które pozostawiają niewiele swobody w sposobie ich wykonywania. [...]. «Bruksela» - a w rzeczywistości Rada Ministrów Rybołówstwa - jest postrzegana jako decydent przesądzający o każdym najmniejszym szczególe realizacji założeń polityki rybołówstwa"22. Założenia obecnej WPR wydają się racjonalne - najpierw dla wód należących do UE określa się maksymalne ilości ryb, które można wyłowić w danym roku (tzw. TAC), które to ilości są dzielone pomiędzy poszczególne kraje członkowskie na podstawie historycznych praw połowowych (brane są pod uwagę rozmiary połowów prowadzonych przed wprowadzeniem WPR). Poszczególne państwa odpowiadają za przestrzeganie i podział przydzielonych im kwot połowowych między swoje floty rybackie.

Racjonalność kończy się, gdy trzeba ustalić ogólną pulę połowów dla całej Unii. Pierwsza propozycja wychodzi od naukowców, którzy dbają o to, aby w następnym roku populacja unijnych ryb miała szansę się odbudować. Ta propozycja trafia do Komisji Europejskiej, która [...] hojnie podwyższa limity połowowe. $\mathrm{Nad}$ propozycją Komisji [...] obradują ministrowie [rybołówstwa] z państw członkowskich, którzy podwyższają limity. [...] Na dodatek państwa członkowskie $[\ldots]$ przymykają oko na nielegalne połowy prowadzone przez swoich rybaków, czyli (jak twierdzi sama Komisja Europejska) na kolejne 30\% ponad „naukowe" limity połowowe ${ }^{23}$.

Opisana wyżej sytuacja spowodowała, że w kwietniu 2009 roku Komisja Europejska rozpoczęła konsultacje publiczne przygotowujące kolejną reformę WPR ${ }^{24}$. W tym celu przygotowano tzw. „Zieloną Księgę” (powoływaną już uprzednio kilkakrotnie w artykule). Jej stworzenie miało na celu: (1) ugruntowanie w świadomości obywateli, a w szczególności w społecznościach związanych $\mathrm{z}$ rybołówstwem, konieczności wprowadzenia reformy; (2) wypracowanie efektywnych rozwiązań w zakresie zarządzania wspólnymi w UE zasobami ryb

${ }^{22}$ Ibidem, s. 12. Niektóre państwa członkowskie z rozwiniętym sektorem rybołówstwa (np. Francja ustala ceny minimalne) regularnie ubiegają się o wyjątkowe traktowanie. Potem często wprowadza się uzupełniające działania, które mają niwelować negatywne skutki ekonomiczne tego szczególnego traktowania, a to z kolei znacznie zwiększa stopień skomplikowania odpowiednich przepisów prawnych.

${ }^{23}$ Ł. Wójcik, op. cit.

${ }^{24}$ Por. np. Unia Europejska przed radykalna reforma Wspólnej Polityki Rybotówstwa, strona internetowa http://www.gazetaprawna.pl z 22.04.2009 r. 
morskich. Zgodnie z postawioną w „Zielonej Księdze” diagnozą 25 główne słabości prowadzonej wcześniej unijnej polityki rybołówstwa to:

- słaba elastyczność i niska efektywność gospodarcza nadmiernie rozrośniętego sektora rybołówstwa;

- nadmierna centralizacja systemu podejmowania decyzji, skierowanego bardziej na realizację krótkoterminowych ${ }^{26}$ celów poszczególnych krajów członkowskich niż na długofalowe zrównoważenie połowów (duży sektor rybołówstwa to silne upolitycznienie decyzji, które skutkuje brakiem poszanowania dla biologicznie określonych ograniczeń kwot połowowych);

- nieefektywność obowiązujących rozwiązań instytucjonalnych skutkujących niską odpowiedzialnością rybaków za istniejące zasoby.

$\mathrm{Z}$ zapowiedzi Komisji Europejskiej wynika, że po zreformowaniu Wspólnej Polityki Rybołówstwa troska o zachowanie zasobów ma być ważniejsza niż utrzymanie miejsc pracy w rybołówstwie. Problemy nieefektywnego, przerośniętego sektora rybołówstwa ma teraz rozwiązywać Europejski Fundusz Rybacki ${ }^{27}$. Jednakże dotychczasowe rezultaty działań w tym zakresie pozwalają mieć uzasadnione wątpliwości co do skuteczności tych działań - przykładowo tonaż francuskiej floty rybackiej w latach 2004-2007 został zredukowany tylko o około 2,5\%. Ponadto niska efektywność flot europejskich nie wynika tylko z ich rozmiarów, ale i rozdrobnienia, którego podstawową przyczyną jest zakaz rynkowego obrotu kwotami połowowymi pomiędzy poszczególnymi rybakami (z obawy przed ich „zmonopolizowaniem” przez dużych armatorów). Poszczególni rybacy nie mogą zakupić dodatkowych kwot połowowych, więc nie mają motywacji, by podnosić swoją wydajność, tym bardziej że ich miejsca pracy są często dotowane.

Rozważa się wprowadzenie rozwiązań, obowiązujących w Islandii ${ }^{28}$, Norwegii, Nowej Zelandii czy Australii. W tych krajach indywidualne kwoty połowowe zostały przydzielone rybakom raz na zawsze - tym samym zdefiniowano silne prawa własności do określonych udziałów w zasobach ryb. Ponadto dozwolony jest handel tak zdefiniowanymi prawami własności do kwot połowowych. Takie rozwiązania instytucjonalne zwiększają wydajność ekonomiczną rybołówstwa najwięksi armatorzy skupują limity od drobnych rybaków, którzy za środki uzyskane $z$ tej sprzedaży mogą się przebranżowić. W rezultacie dochodzi do odpowiedniej redukcji floty poprzez zlikwidowanie najmniej rentownych jednostek, do koncentracji limitów w rękach efektywnych armatorów, a dzięki temu połowy stają się tańsze. System taki wymusza na rybakach dbałość o łowiska, bo ilość i jakość

${ }^{25}$ Zielona Księga..., s. 9-16.

${ }^{26}$ Działania mające na celu zachowanie zasobów rybnych podejmowano w cyklu rocznym.

${ }^{27}$ Cele działań Europejskiego Funduszu Rybackiego na lata 2007-2013 opisuje dokument dostępny na stronie: http://ec.europa.eu/fisheries/publications/FEP_PL.pdf.

${ }^{28}$ Islandia nie przystąpiła do UE między innymi ze względu na unijną politykę rybołówstwa. 
ich zasobów mają istotny wpływ na wartość praw własności do indywidualnych kwot połowowych. Ponadto nie ma tu potrzeby wprowadzania państwowych subsydiów, bo redukcja i koncentracja - a w konsekwencji długoterminowa efektywność - zostają osiągnięte dzięki koordynacyjnemu działaniu mechanizmów rynkowych. Ważną (i zapewne konfliktową) kwestią jest tu początkowe nadanie praw własności do limitów połowowych - Komisja Europejska postuluje, by zajmowały się tym specjalne komitety regionalne, reprezentujące zainteresowane grupy krajów, a nie - jak do tej pory $-\mathrm{z}$ natury upolitycznieni ministrowie poszczególnych państw UE na zcentralizowanych obradach w Brukseli.

\section{ZAKOŃCZENIE}

Przedstawiony proceder przekraczania biologicznych limitów połowowych w Unii Europejskiej można chyba nazwać wielopoziomową czy wieloetapową „jazdą na gapę”, a jej skutkiem jest rzeczywista przyrodnicza tragedia. Przykład dotychczasowego gospodarowania wspólnymi, europejskimi łowiskami pokazuje też, że wykształcenie efektywnych rozwiązań instytucjonalnych może być trudne w sytuacji silnego konfliktu politycznego pomiędzy państwami korzystającymi z tego typu wspólnych zasobów. W opisanym przypadku podstawowymi powodami „tragedii dóbr wspólnych” są błędy państwa, wynikające ze scentralizowanego sposobu ustalania limitów odłowień (opartego na konsensusie politycznym), oraz brak odpowiedniego rynku, na którym byłby możliwy handel uprzednio zdefiniowanymi prawami własności do kwot połowowych - rybacy, nie mogąc ich sprzedać, nie mają interesu w dbaniu o swoje łowiska (bardziej zależy im na krótkoterminowym zysku niż na utrzymaniu w użytkowanym akwenie zdolnej do reprodukcji populacji ryb). Ponadto sektor rybołówstwa nie może funkcjonować w oderwaniu od innych obszarów gospodarki morskiej - coraz większe połacie mórz i wybrzeży wykorzystywane są do konkurencyjnych zastosowań, jak turystyka czy transport, co z kolei stwarza możliwości przekształcenia struktury zatrudnienia społeczności stref przybrzeżnych i zróżnicowania jej dochodów. Dotychczasowa ingerencja państwa w problemy rybołówstwa UE skoncentrowana nadmiernie na utrzymaniu miejsc pracy - jak się wydaje - nie wykorzystywała należycie potencjału koordynacyjnego działania mechanizmów rynkowych. 


\section{GOVERNMENT FAILURES IN SOLVING THE TRAGEDY OF THE COMMONS - THE EXAMPLE OF EU COMMON FISHERIES POLICY}

SUMMARY

The tragedy of the commons occurs when too many users extensively use public goods, such as common pastures, fisheries, roads, etc. This phenomenon can be analyzed as a subcategory of the free riding problem which causes the market coordination of producing public goods to be usually inefficient. However, as is shown in the paper (particularly based on the UE fisheries policy), defining strong property rights to common resources (and allowing the trading of these rights) may be the effective solution to the tragedy of the commons. 

II. MISCELLANEA 
